\title{
Explaining the Dimensions and Components of Smart Governance in Tehran
}

\author{
Shahram Parsa ${ }^{1, *}$, Ahmad Pourahmad ${ }^{1}$, Mikael Parsa ${ }^{2}$, Esmail Piri ${ }^{3}$ \\ ${ }^{1}$ College of Tehran Geography, Tehran University, Tehran, Iran \\ ${ }^{2}$ College of Kharazmi Management, Kharazmi University, Tehran, Iran \\ ${ }^{3}$ College of Allameh Tabatabi, Allameh Tabatabi University, Tehran, Iran \\ Email address: \\ shahramparsa.phd@gmail.com (S. Parsa), sh_pashabadi@yahoo.com (S. Parsa), apoura@ut.ac.ir (A. Pourahmad), \\ mikaelparsa@gmail.com (M. Parsa), asmailpiriii@yahoo.com (E. Piri) \\ ${ }^{*}$ Corresponding author
}

\section{To cite this article:}

Shahram Parsa, Ahmad Pourahmad, Mikael Parsa, Esmail Piri. Explaining the Dimensions and Components of Smart Governance in Tehran. International Journal of European Studies. Vol. 5, No. 1, 2021, pp. 7-22. doi: 10.11648/j.ijes.20210501.12

Received: August 22, 2020; Accepted: September 14, 2020; Published: April 29, 2021

\begin{abstract}
The Smart City is a multi-dimensional concept, composed of many components and dimensions. Meanwhile, smart governance has been regarded as a vital cornerstone of the smart city and one of its key dimensions and starting point. In this research, the dimensions and components of smart governance in Tehran are discussed. The research method in this study is descriptive-analytical. Research data collection is based on documentary and survey method. The data collection tool in this study consists of a researcher-made questionnaire with closed-ended questions (Likert's five-choice range). The sampling method is cluster random sampling. The statistical population of this study is all residents of Tehran based on population and housing census of 2016 which includes 8693706 population. The number of samples was estimated to be 384 according to Cochran formula. The number of samples based on four main clusters of the population between class was divided into five districts. To analyze the data from objective statistics as well as to analyze the citizens' views of the one-sample t-test to assess the status of the indicators, the Friedman test for ranking the indicators in different neighbourhoods, and then on the total constraints studied in Tehran and from Kruskal-Wallis test was used to compare indices in different neighbourhoods. The results of this research on smart governance indicators (decision making, partnership, collaboration, internal and external coordination, innovation capacity, technology, e-government and public services) in Tehran show that two basic dimensions of governance (partnership)., Partnerships, and decision making systems) are below average, which indicates the weak role and status of citizens in the decision-making system. The situation of other smart governance indicators in Tehran is also moderate.
\end{abstract}

Keywords: Smart City, Smart Governance, Governance Dimensions, Tehran City

\section{Introduction}

Cities have evolved over time under the influence of different paradigms. Urban development paradigms have long been one of the primary areas in which socio-economic and political schools of thought are involved. Smart City is one of the latest trends in urban development that has emerged since the early 1990s in the wake of the smart growth movement. This concept is addressed in response to contemporary global challenges such as accelerated urbanization, increased greenhouse gas emissions and $70 \%$ of cities' emissions, economic competitiveness, etc. And it means opening up new concepts in urban planning that combine the capabilities of the real and virtual worlds to solve urban problems. Cities are now faced with complex and widespread interconnected challenges that transcend their capacities and capabilities, stemming from their traditional institutions and classical processes. Therefore, innovative forms of governance are needed to meet these challenges. Therefore, in many countries around the world, to address the problems of cities that cannot be solved by classical approaches, the virtual world approaches and solutions to maximize the potential of urban life and reduce their problems. However, there is no way to be smart. Meanwhile, different cities have adopted different approaches, reflecting 
their particular circumstances, but what is true is that smart technologies have led to widespread developments in all areas of human life and have served as a platform for the growth and development of other sectors in various dimensions. Therefore, the smart city as a new way of urban life to solve problems can be formed parallel to the real city and with the help of physical space to expand and expand the real capacity of the city. In fact, we are embarking on a new journey in the field of smart cities that challenges our intellectual foundations about urban spaces due to the rapidly expanding and changing ICTs of everyday life. So smart cities will create new spaces that combine traditional ideas and real space with new technologies and cyberspace that will transform the style and lifestyle of the city and its development process so that processes New economic and social accountability in the new body. So smart city as the axis of development and the Millennium Development raised. Despite the fact that many similar terms have emerged so far in smart cities (wireless communities, digital cities, networking communities, etc.), these concepts have been used interchangeably by various researchers, but all this suggests that societies have begun a conscious effort to understand and participate in a highly connected world. The idea of creating smart cities leverages the power of knowledge embedded in big, heterogeneous data in the urban space to solve the underlying problems facing cities today. The enormous data generated in the city space, along with the advances in information and communication technology, provide unprecedented opportunities to meet the enormous challenges facing cities. A review of the literature in this area shows that the smart city has various integrated dimensions (smart economy, smart people, smart environment, smart mobility, smart living and smart governance). In the meantime, smart governance is one of the core dimensions of the smart city that is based on inclusive and active citizen, public and private participation [22]. The current governance structures in many governments require little citizen involvement in decision-making and planning of urban development and are largely based on a bureaucratic model of governance. This model is not able to effectively reflect the relationship of government and other actors in the age of information and communication technology. In addition, the responsibility for various services across multiple institutions and organizations is fragmented, making this situation even more complex for every citizen. Meanwhile, Tehran as the capital of Iran and the largest city in the country, the high concentration of population in the city, despite the concentration of various facilities and services in it, facing a variety of complex problems and problems such as pollution, traffic and... Much of this is due to the way the city is run and the attitude of the city managers in different sectors. In the meantime, the idea of the smart city seems to be able to rush to real space to alleviate city problems and it will be useful in promoting the quality of life of citizens in different dimensions and in strengthening Tehran's transnational status and role in view of the global interconnectedness of cities. The inefficiency of city administration practices and the complexity of the growing problems and problems of cities, especially metropolises, including Tehran, have led to new development paradigms, including smart city and smart governance, on the development and necessity of active social actors and interaction and continuous interaction. And effective all of them, In this way, we will use all the potentials and capabilities for comprehensive development and only by consensus of views and different sources that can be fair conditions and quality of life in cities and against all improved. The purpose of this article is to explain and evaluate the dimensions of smart governance in Tehran. We hope the project and clarifying the concept of smart governance and the structure of its main small step toward bridging the gap theory and practice in the field is removed. In general, this article seeks to answer the following questions:

1) What is the status of smart governance in Tehran?

2) The importance of smart governance elements in each of the areas studied in Tehran today?

3) What is the priority of each of the benchmarks (smart governance) in different neighbourhoods?

\section{Research Method}

The research method in this research is descriptiveanalytical. In terms of purpose, it is fundamental-applied as it attempts to explain and measure the dimensions of smart governance through in-depth literature on smart cities. Research data collection is based on documentary and survey method. The data collection tool in this study consisted of a researcher-made questionnaire with closed-ended questions (Likert's five-choice range). The sampling method in this study is cluster sampling. So that the city of Tehran (22 districts), according to the research topic, was divided into four sections based on the status of households' access to the Internet. Then, five regions were randomly selected (two samples were selected in one cluster given the number of regions). Then, in each of the five zones, one district and then in each district were finally randomly selected for sampling. Then, in each of the five zones, one district and then in each district were finally randomly a neighbourhood selected for sampling. The statistical population of this study is all residents of Tehran city which according to the general population census and housing in 2016 is 8693706 population. The sample size was 384 according to Cochran formula, 420 questionnaires were distributed among different individuals (to ensure the return of the required sample size) 387 were completed and used in the analysis. They were not given or were incompletely answered and deleted. The number of samples was stratified according to the population of four main clusters selected among the five regions. The sample number is based on Cochran's formula as follows. To analyze the data from objective statistics as well as to analyze the citizens' views of the one-sample t-test to assess the status of the indicators, the Friedman test for ranking the indicators in different neighbourhoods, and then on the total constraints studied in Tehran and from Kruskal-Wallis test was used to 
compare indices in different neighbourhoods.

$$
n=\frac{\frac{z^{2} p q}{d^{2}}}{1+\frac{1}{N}\left[\frac{z^{2} p q}{d^{2}}-1\right]}=\frac{\frac{(1 / 96)^{2} \times(. / 5) \times(. / 5)}{(. / 05)^{2}}}{1+\frac{1}{8693706}\left[\frac{(1 / 96)^{2} \times(. / 5) \times(. / 5)}{(. / 05)^{2}}-1\right]}=384
$$

Table 1. Selected Areas for Sampling.

\begin{tabular}{lllll}
\hline Internet access rate (\%) & Less than 15\% & $\mathbf{1 6 - 3 0 \%}$ & $\mathbf{3 1 - 4 5 \%}$ \\
\hline Internet access status in areas & $15-17-18-19$ & $4-9--10-11-12-13-14-16-20$ & $5-7-8-22$ \\
Selected areas & 17 & 11 & 4 & 5 \\
Selected neighbourhoods & Yaftabad & Eskandari & Western Tehran Pars & South Jannat Abad \\
Number of samples & 79 & 72 & 82 & 84 \\
\hline
\end{tabular}

Source: Authors

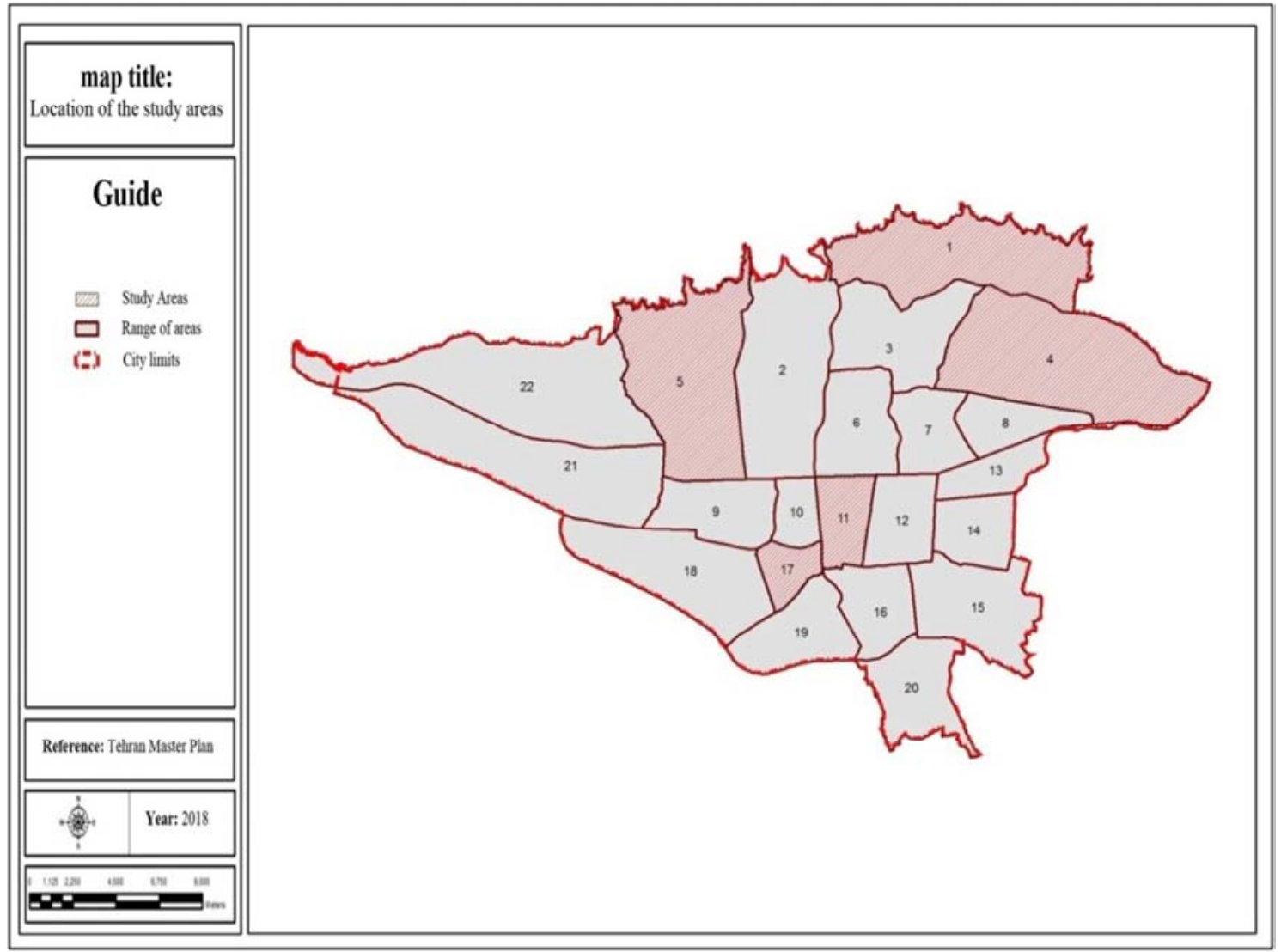

Figure 1. Location of the study areas.

\section{Theoretical Foundations}

\subsection{Smart City}

The concept of a smart city has just been introduced and can be considered as an urban development capable of integrating previous paradigms (social welfare, neoliberal and self-organized). With a strong emphasis on technology, connectivity and open information, smart cities have the potential to transform citizens as active partners in publicprivate forms of urban development. If implemented through a horizontal partnership. Smart cities potentially offer an opportunity to overcome the traditional division between urban actors. The first step is to create a smart city, understand its concept. However, a brief review of the relevant literature in this area shows that the concept of a smart city is highly controversial. In fact, the emergence of similar terms such as cities of intelligence, virtual city, knowledge city, and the digital city has added to the conceptual confusion of this term [42]. A smart city is often defined by its goals and smart is defined as more efficient, sustainable, equitable and livable [1]. These terms refer to the less general and specific levels of a city, so the concepts of smart cities often include them. Smart City is a model of urban development that is created by the interaction of different actors (citizens, actors of the public and private sector) and represents a range of different goals and characteristics. Thus the smart city is a multidimensional concept with multiple goals [8]. The concept of a smart city first examines the city as a system with multiple subsystems. This performance of the subsystem as a whole ultimately allows them to behave in a smart and coordinated manner [12]. In other words, as the city is a complex system of interactions between subsystems is varied and 
unpredictable. The goal of the smart cities model is to find appropriate solutions to manage this complexity, especially by addressing the negative consequences of global urbanization and higher quality of life for the urban population [36[. The ultimate goal of the smart city is to provide smart services in all the vital capabilities of the city. There are different views in this regard in the literature. Some authors have focused on producing better policy outcomes in terms of wealth, health and sustainability. Others have focused on enhancing citizen participation and open forms of cooperation. The first view focuses on the content of government actions. The second view, however, emphasizes the processes of governance. In the field of urban planning, the term smart city is often seen as an ideological dimension whereby smart requires strategic orientations. Governments and public institutions at all levels have used the concept of smart to identify their programs and policies with the aim of sustainable development, economic growth, the better quality of life for citizens, and the creation of happiness and prosperity [2]. The concept of a smart city is not limited to the dissemination of information and communication technology. So the smart city concept is not limited to the dissemination of information and communication technology, people and society need to be considered. Betty et al. (2013) highlight these dimensions and emphasize that the influence of ICTs in cities should improve the performance of each subsystem in order to enhance the quality of life. Nam and Pardo (2011) argue that the difference between the concept of smart city and other related terms such as the ubiquitous, digital, and intelligent city lies in the three categories of technology, people and societies. Caragliu et al. (2009) add that the aim of achieving social inclusion urban residents in public service [9]. Many authors have outlined the overall goals of the smart city. But Courtyatt et al. (2012) emphasize that the smart city must be proportional to the dependencies (attributes and characteristics) of the historical growth path, although to a certain extent all cities face similar problems. Social inclusion may be an important goal for smart cities with a divided population, while health may be more important. In addition, the goals of cities depend on what is important to the urban population. The key point is that few authors emphasize the intrinsic nature of urban systems, and the discourse on smart cities is one of the best cities under the influence and dominance. One of the cities is generally depicted as the best city for the whole population. Among the definitions provided for Smart City, the following seems more comprehensive: "Smart City is a sustainable and highquality city with high quality of life that aims to tackle urban challenges (improving mobility, optimizing resource use, improving health and security, improving social development, supporting economic growth and participatory governance). Through the use of information and communication technologies in services and infrastructure, the collaboration between key stakeholders (citizens, universities, government and industry) and investing in social capital is» [35]. Here, one of the main aspects of the smart city (the cornerstone of the smart city), namely the smart governance (the main topic of the article), is discussed.

\subsection{Smart Governance}

The World Bank defines governance as the way in which the power of managing a country's social and economic resources is used for development [20]. It refers to the processes of interaction and decision-making among actors involved in collective issues that lead to the production, reinforcement, or reproduction of social institutions and norms. In smart governance, the interaction of government with citizens is based on information and communication technology [3]. In the meantime, some have conceptualized governance as nothing more than the governance of a smart city, while others have identified it as innovative decisionmaking, innovative management or even innovative forms of collaboration [33]. In general, there are two views on smart governance, the conservative view that existing institutional arrangements can lead to smart cities and the transformation of government processes and structures are not needed. In this sense, smart governance is merely the governance of a smart city, and smart governance is about making the right political choices and implementing them effectively and efficiently. In this view, this transformation can take place within existing structures. But the radical view is that the government itself must be transformed to create a smart city. Bety et al. (2012) believe that smart governance is merely a feature associated with the organizational management of a city, where it makes itself smart. Giffinger et al. (2012) emphasize that smart governance also includes political participation, service to citizens, as well as government performance. Alkandri et al (2012) argued that the government should approve the development of smart cities. Winters (2012) argues that urban governments should simply develop higher education centres to develop smart cities [51]. Nam (2012) emphasizes that governance is about promoting smart city plans. Schurman defines smart governance as the process of collecting data and information about public management through a sensor or sensor network. Gial Garsia (2012) points out that a smart government is a new form of smart governance that utilizes sophisticated information technologies to interact and integrate information, processes, institutions and physical infrastructure to better deliver services to citizens. This type of smart governance is at a higher level than evolution. It, therefore, requires the reorganization of internal organizations. The government needs to innovate to meet the requirements of different policies. Caragliu et al. (2012) state that the characteristics of specific spaces can influence the development of smart cities. As a result, there is a need for geopolitical conventional political action. Smart governance is the re-arrangement of government within the urban system. Batagen (2012) believes that smart governance means working across ministries and with communities that contribute to economic growth and improvement, better citizen-centric performance and services. Tapscott and Agnew (1999) emphasize that intelligent governance is the widespread adoption of a fully social-centric model with greater connectivity facilitated by 
new technologies. Schuurman et al. (2012) believe that government in smart cities should play a key role in promoting and engaging all relevant stakeholders in order to create an interactive, participatory and information-based urban environment [2]. Meijer emphasizes the structural appropriateness between government and society and points out that the information society needs a new form of governance [33]. Citizens in smart cities are encouraged to be creative, higher education, and open to communication and learning, and this can be achieved by breaking the boundaries of knowledge. Instead, it allowed the free flow of information between people through a comprehensive and transparent system [16]. Nam and Pardo point out that the main purpose of government in smart cities is to create a transparent and integrated governance system and engage in strategic and promotional activities and to achieve stakeholder participation in the city. To achieve this vision, smart cities need comprehensive, multi-faceted approaches to planning and decision-making processes that emphasize partnerships between government, stakeholders, and citizens [38]. In addition, it is imperative that urban management landscape [14], goals [19] share the priorities of their smart cities strategic plans with the general public and relevant stakeholders [15]. Successful initiatives are the result of business, education, government, and individual citizen coalitions [31]. A successful smart city can be built on a top-down or bottom-up approach, but the active involvement of every part of society is essential. Urban management must share concepts (advertising identity and brand), perspectives, goals, priorities and even strategic plans of the smart city with the general public and stakeholders. The support of local leaders in the smart city landscape is crucial to their success. The role of leadership is central both within the government and in communicating with citizens [38]. Developing an efficient and effective government is a prerequisite for the development of smart cities. This involves intervening in three main ways: A) By playing a coordinating role, creating different interests and bringing together different stakeholders to create a new platform for collaboration; (B) through the role of a financial sponsor, including the financing of infrastructure and executive projects; C) By acting as a regulator and by ensuring that common standards and regulations are in place. This vision requires an integrated view of the city and all its infrastructure components. In fact, innovation by local authorities requires vision and leadership. The smart government must, therefore, deal with 1- complexity. 2) uncertainty and should create 3 ) competencies and 4) achieve flexibility [28]. Therefore, local governments are recognized as key players in creating an interactive, participatory, information-driven urban environment with the ultimate goal of generating public value and increasing wealth, achieving a high quality of life for citizens. Thus, in smart cities, governance involves cooperation, partnerships, partnerships, participation, and citizen engagement [13]. The realization of smart governance requires deep and meaningful engagement. For deep engagement to occur, smart cities need to transform electronic governance options from monologues in which planners or government officials provide information to citizens (Two-way dialogue where citizens and officials interact with the two-way communication). Citizens want such opportunities for meaningful communication from their local governments. There is enough evidence to show that citizen participation offers real benefits [21, 27]. For example, citizen participation can enhance policy enforcement, increase purchases, minimize potential conflicts, create human capital, and improve policymaking. Thus smart cities are cities that use technology to promote overall sustainability if sustainability is defined as the right balance between environmental, economic, and justice goals. So governance can play an important role in finding this interaction. Therefore smart cities promote smart governance. Smart governance must be transformational. In this regard, smart cities emphasize three principles: knowledge creation and consolidation, equitable and widespread knowledge dissemination, and meaningful deep interaction. Transparency has been argued to be at the core of three principles, and smart cities are transparent cities [18]. So it's not about the governments doing what they do, it's about the results of interactions between all actors in the public domain. Therefore, smart governance may be a new form of deep, meaningful collaboration, coordination, and interaction between people, organizations, institutions, and the private sector through information and communication technology to produce and disseminate information and transform it into knowledge to generate public value (Social innovation, social learning, sustainability, equal opportunities, more open governance processes, social inclusion, better service delivery, etc.).

Table 2. Definition of smart Governance.

\begin{tabular}{|c|c|}
\hline Definition & References \\
\hline Smart governance includes the dimensions of political participation, services to citizens, and also the functioning of government. & [24] \\
\hline Smart governance is the promotion of smart city initiatives. & [37] \\
\hline Smart governance is the decision-making process, and it is implemented (or not implemented) through network technology decisions. & [48] \\
\hline $\begin{array}{l}\text { Smart governance means working across sectors and organizations with communities, helping to promote economic growth and at many } \\
\text { important levels of citizen-centric operations and services. }\end{array}$ & [5] \\
\hline Smart Governance points to the very strong intelligence function of coordinating the many different components that make up the smart city. & [6] \\
\hline $\begin{array}{l}\text { Good governance or smart governance often refers to the use of new channels of communication for citizens, such as e-governance or e- } \\
\text { democracy. }\end{array}$ & [23] \\
\hline The overall goal of smart governance can be to achieve social inclusion of urban residents in public services. & {$[10]$} \\
\hline
\end{tabular}




\begin{tabular}{lll}
\hline Definition & References \\
\hline Smart governance, open and dynamic governance structures are involved with all actors in order to maximize the environmental and socio- & [30] \\
economic performance of cities and counteract the negative side effects and dependence of the historical growth path. & [46] \\
The widespread adoption of a fully integrated, more interconnected governance model facilitated by new technologies. & [4] \\
Smart cities need to develop smart governance systems that take into account all the key factors. A three-step process is suggested, starting & [50] \\
with identifying the conditions (cognition) then developing the strategic plan and finally taking action. & [50] \\
Smart governance is a set of principles, elements, and capacities that create a form of governance that is capable of dealing with a & [40] \\
knowledge-based society. & Smart governance is the activity of coordinating communications to achieve collective goals through collaboration. \\
Electronic governance refers to the ability of government agencies to interact with the general public online in delivering services and \\
performing assigned tasks. \\
Smart government is a new form of e-government that utilizes sophisticated information technologies to integrate, integrate and integrate \\
physical information, processes, institutions, and infrastructure to better serve citizens and society. \\
\hline
\end{tabular}

[7]

Table 3. Some dimensions of smart governance in the literature.

\begin{tabular}{|c|c|}
\hline Dimensions & References \\
\hline $\begin{array}{l}\text { 1. Information and communication technology 2. Collaboration 3. Internal coordination 4. Decision-making process 5. Electronic affairs } \\
\text { department } 6 \text {. Results and achievements. }\end{array}$ & [34] \\
\hline 1. Command 2. Boundary Conditions 3. Alignment Dimensions 4. Dependency Dimension 5. Role of Local Governments & [7] \\
\hline $\begin{array}{l}\text { 1. Government 2. Leadership 3. Actors and stakeholders 4. Municipal and participatory governance 5. Partnerships, partnerships and } \\
\text { partnerships }\end{array}$ & {$[17]$} \\
\hline $\begin{array}{l}\text { 1. Collaboration 2. Leader and Hero 3. Collaboration and Collaboration 4. Communication 5. Information Exchange 6. Integration of } \\
\text { Services and Applications 7. Transparency }\end{array}$ & [12] \\
\hline 1. Participation in decision-making 2. Transparency 3. Social and public services 4. Leadership and vision & [45] \\
\hline $\begin{array}{l}\text { 1. Building and Managing a Community 2. Developing a Strategy and Outlook 3. Creating Public Value 4. Asset Management 5. Economic } \\
\text { and Financial Sustainability }\end{array}$ & {$[11]$} \\
\hline 1. Coordination and integration 2. Service integration 3 partnerships and co-production 4 . Policies and regulations & [18] \\
\hline 1. E-Government 2. Shareholders and Citizens 3. Community 4. Interaction, Networking, Partnerships and Collaboration & [26] \\
\hline
\end{tabular}

Source: Authors

\subsection{Dimensions of Smart Governance}

Paying attention to smart governance is a key aspect of growing smart cities. But its conceptual understanding is still very limited. The lack of consensus on the definition of a smart city has also led to the reproduction of dispersed interpretations in the concept of smart governance. Although there is a different approach to the concept of smart city governance in previous research [34], none have mentioned the best way to govern smart cities. So some smart governance concept as nothing more than smart city governance has not conceptualized. While others use it as an innovative way of decision-making, innovative administration or even innovative forms of cooperation have been considered. Others refer to the claims of legitimacy of governance. As academic journals emphasize economic gains, most studies emphasize transnational outcomes (sustainability) or extracurricular processes (enhancing citizen participation) as the source of government legitimacy. In the meantime, the researchers have divided this concept into several features with the aim of clarifying what constitutes smart governance, citing the complexity of the concept of smart governance in smart cities as a holistic approach. According to the findings of Bolivar and Meijer 1 (2015), six definitional elements cover different aspects of governance (technology, external cooperation and participation, internal coordination, decision-making, e-

1 Bolivar and Meijer, in a research paper in 2015 (called Intelligent Governance; Using Literature Review and Experimental Analysis to Build a Research Model), surveyed the dominance among 70 leading European cities (European cities). governance, and outcomes). They emphasize that these elements are key to smart governance [34]. Meijer and Bolivar (2015), in another similar research work entitled 'Smart City Administration: A Survey of Smart Governance Literature', concludes with 51 scientific works that smart governance formulates new forms of human collaboration through the use of information technology and Communications are more open to achieving better results and governance processes. Smart governance is not a technological issue and smart governance must be studied as a complex process of institutional change and acknowledged by the political nature of the socio-technical governance perspective document [34]. Also, Bolivar (2016) points out in a research paper entitled "Drawing the Dimensions of Governance in Smart Cities" that the concept of smart city has been examined from three major situations: Technologycentered approach, human-centred approach [44] and integrated approach. They believe that the integrated approach of the smart city emphasizes the governance of shareholders and the institutional factors of governance [38], which is considered the cornerstone of smart cities [23]. Thus, the basic concept of governance based on smart cities frameworks is to build structures based on multiple private and public stakeholder negotiation engagements operating at different scales [41]. This not only requires improving the capacity of the public sector, but also the transformation of the role, scope, power, and activities of the government in the economy and society [29]. Damri \& Benevolu (2015) identified five smart city governance labels: government; 
leadership; actors and stakeholders; urban governance and participatory governance, participation, cooperation and partnership. They point out that based on government labels, local government institutions are key components of smart city government $[12,32,36]$.

\section{Discussion and Findings}

\subsection{Survey the Dimensions of Smart Governance in Tehran}

A) North of Tehran (Velenjak neighbourhood)

The results of the survey of smart governance indicators in the north of Tehran (Velenjak neighbourhood) show that all aspects of smart governance except the deciding factor (lower than average) are average. The technology and public services (each with an average of 3.31) are better than the other components. According to the 2011 census, more than 50 per cent of the population of six years old and older had used the Internet (region one with a 50.62 per cent). The computer penetration rate in the northern regions of Tehran is higher than in other areas $(73.2 \%$ of households had computers in Zone 1). Also, Region One has a higher educational attainment (higher than state diploma degree) population than other regions (Region 1, 46.62\%). Also, Region One has a higher educational attainment (state diploma degree) population than other regions (Region1, $46.62 \%)$.

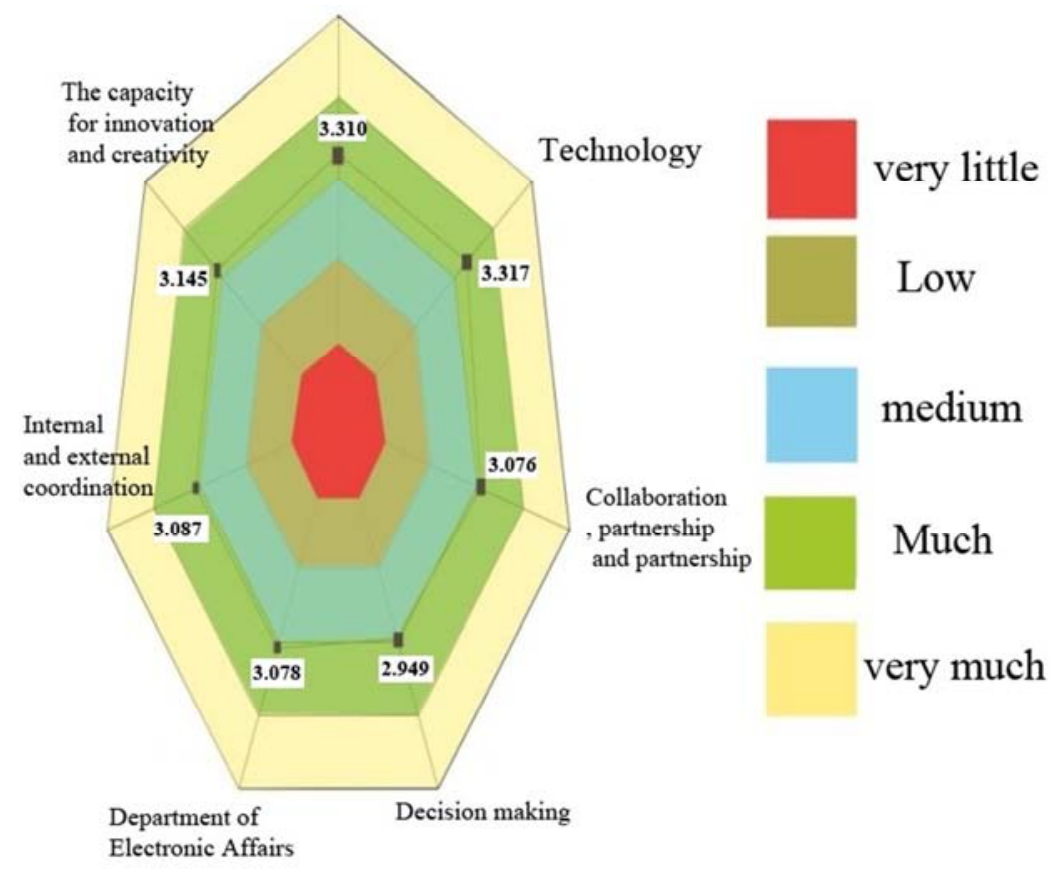

Figure 2. Status of smart governance indicators in the north of Tehran (Velenjak neighbourhood).

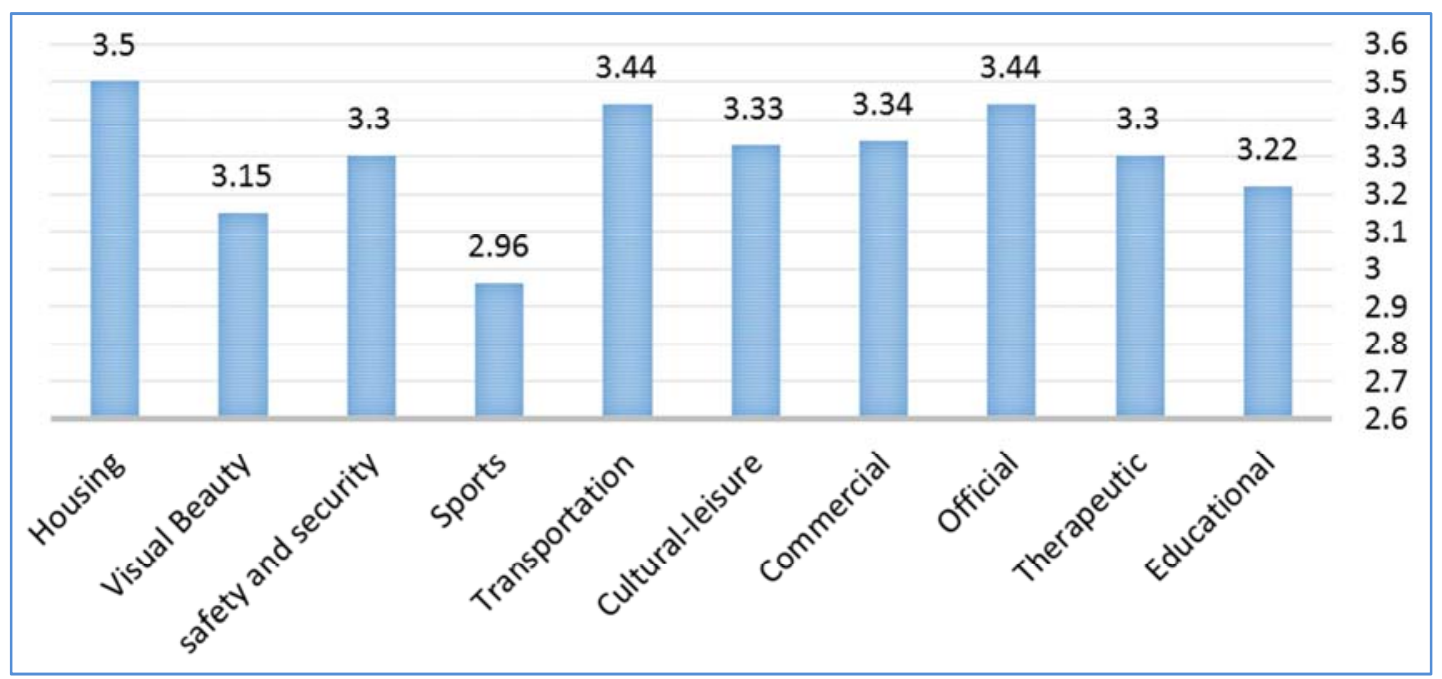

Figure 3. Status of public service sub-indicators in North Tehran (Velenjak neighbourhood).

B) Center of Tehran (Eskandari neighbourhood)

The results of the survey of smart governance indicators in downtown Tehran (Eskandari neighbourhood) show that technology, collaboration, partnerships and decision making 
are intermediate and other criteria are below average. According to the 2011 census, Internet penetration rate among the population of six years old and older in central and old districts of Tehran is less than $30 \%$ (District 11 with
$28.28 \%$ ). In addition, the computer penetration rate in these areas $(53.77 \%)$ is less than $60 \%$ and higher education (higher than state diploma degree) population is less than $30 \%$ (Region11, 26.41\%).

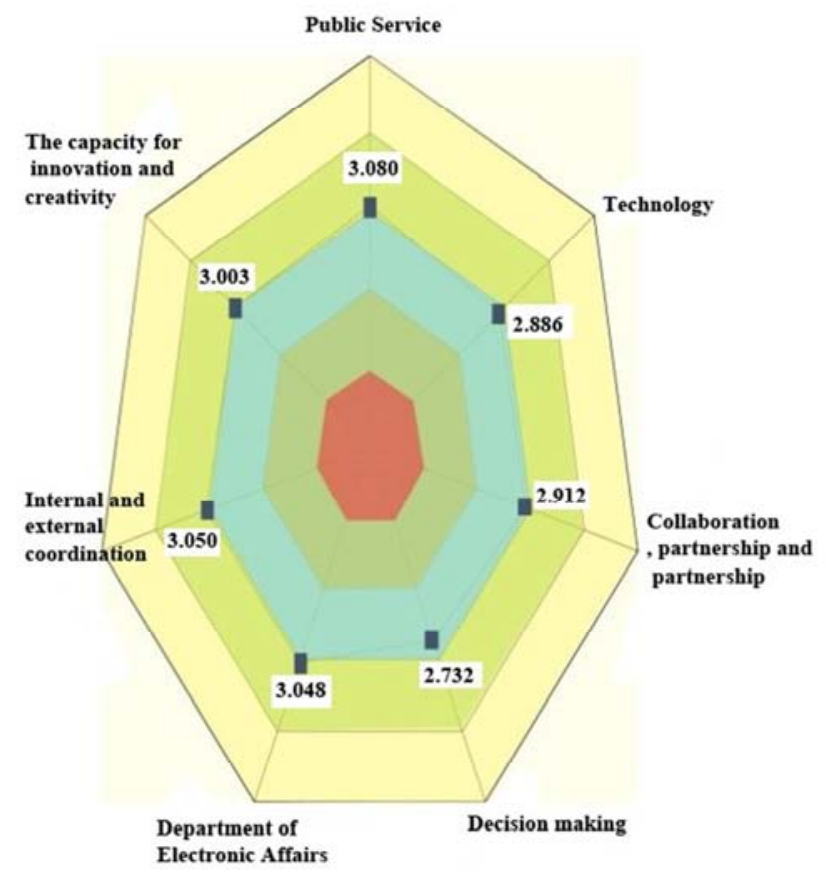

\section{very little}

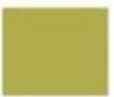

Low

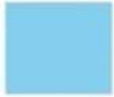

medium

Much

very much

Figure 4. Status of smart governance indicators in central Tehran (Eskandari neighbourhood).

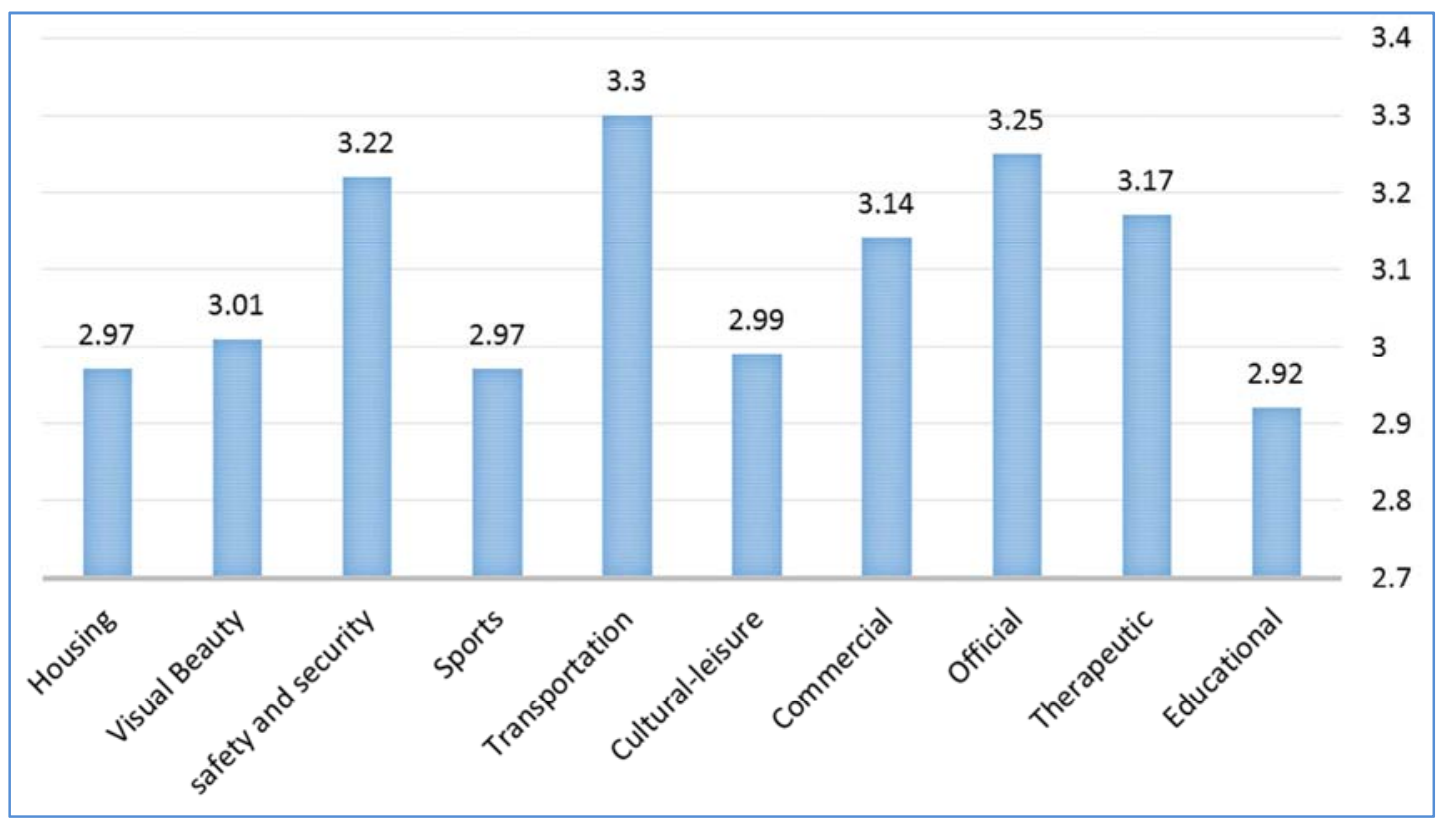

Figure 5. Status of public service sub-indicators in central Tehran (Eskandari neighbourhood).

C) West of Tehran (South Janat Abad neighbourhood)

An examination of the results of a survey of indicators on smart governance in western Tehran (South Janet Abad neighbourhood) shows that except for technological factors, and public services that are average, the rest are lower than average. According to the 2011 census, Internet penetration rate among the population of six years old and older in the western districts of Tehran is less than $45 \%$ (Region five, $42.5 \%$ ). Also, the computer penetration rate in these areas (Regionfive, $73.09 \%$ ) is less than $75 \%$ and the population with higher education (higher than state diploma degree) is less than $41 \%$ (Area 5, 40.56\%). Also, the computer penetration rate in these areas (Region five, $73.09 \%$ ) is less than $75 \%$ and the population with higher education (higher 
than state diploma degree) is less than $41 \%$ (Region five, $40.56 \%$ ).

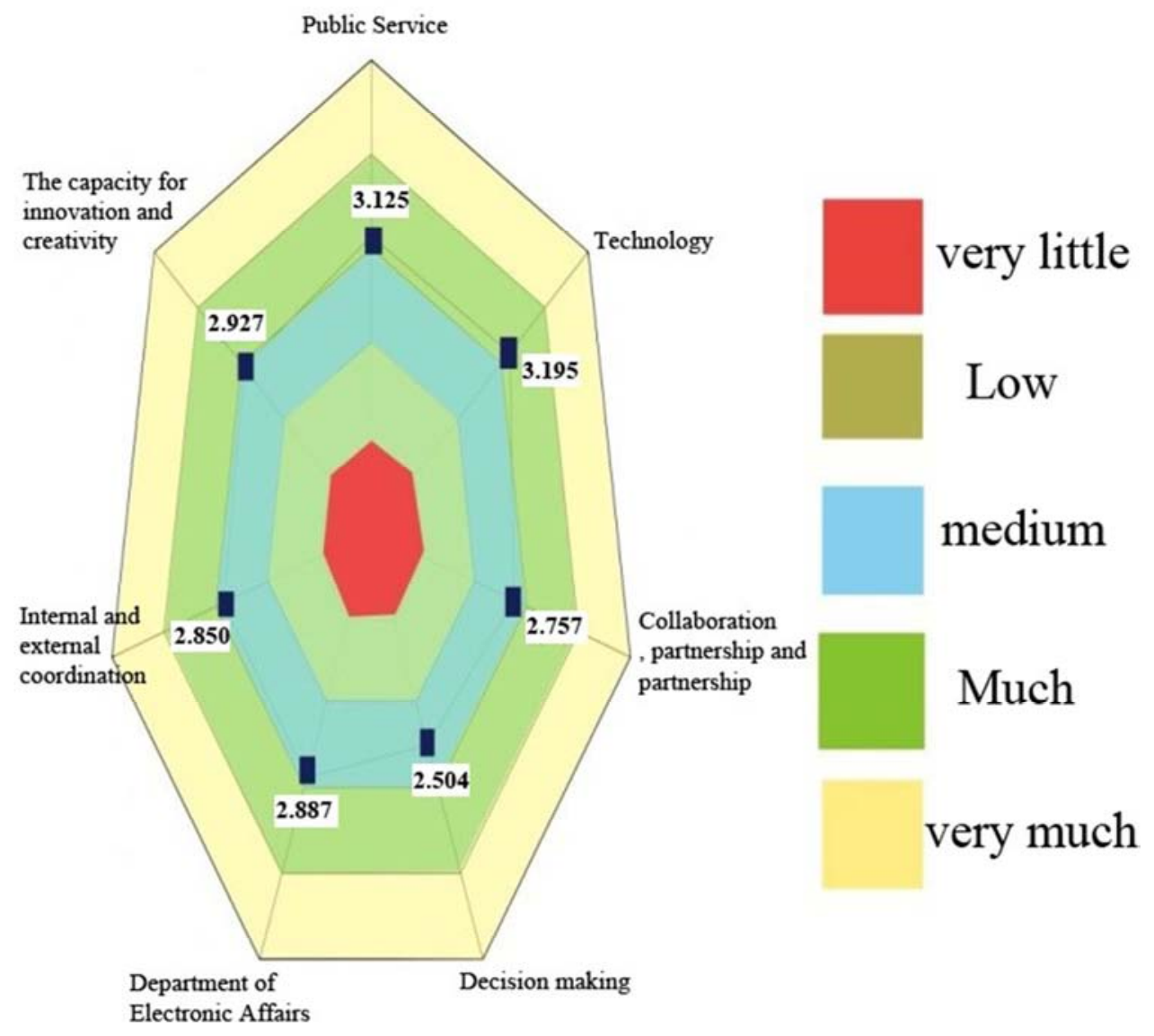

Figure 6. Status of Smart Governance Indicators in West Tehran (South Janet Abad neighbourhood).

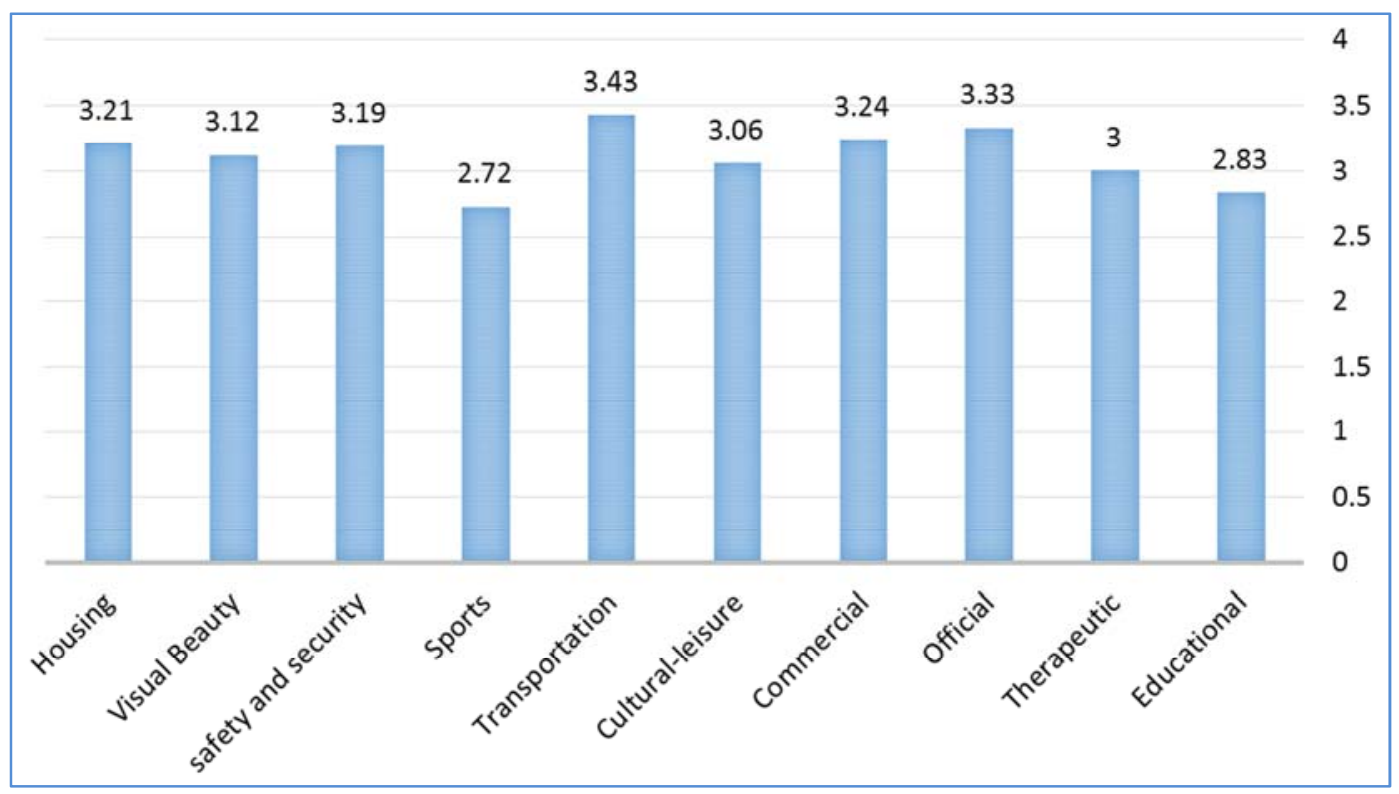

Figure 7. Status of public service sub-indicators in West Tehran (South Janet Abad neighbourhood).

D) East of Tehran (Western Tehranpars neighbourhood)

The results of the survey of smart governance indexes in East Tehran (Western Tehranpars neighbourhood) show that except for the decision factor which is below average, the other dimensions are average. According to the 2011 census, Internet penetration rate among the population of six years old and older in the eastern regions of Tehran is less than $36 \%$ (forth Region, 30.39\%). Also, the computer penetration rate in 
these areas (region four, 58.54\%) is less than $60 \%$ and population with higher education (higher than state diploma

degree) is less than $35 \%$ (region four, $30.09 \%$ ).

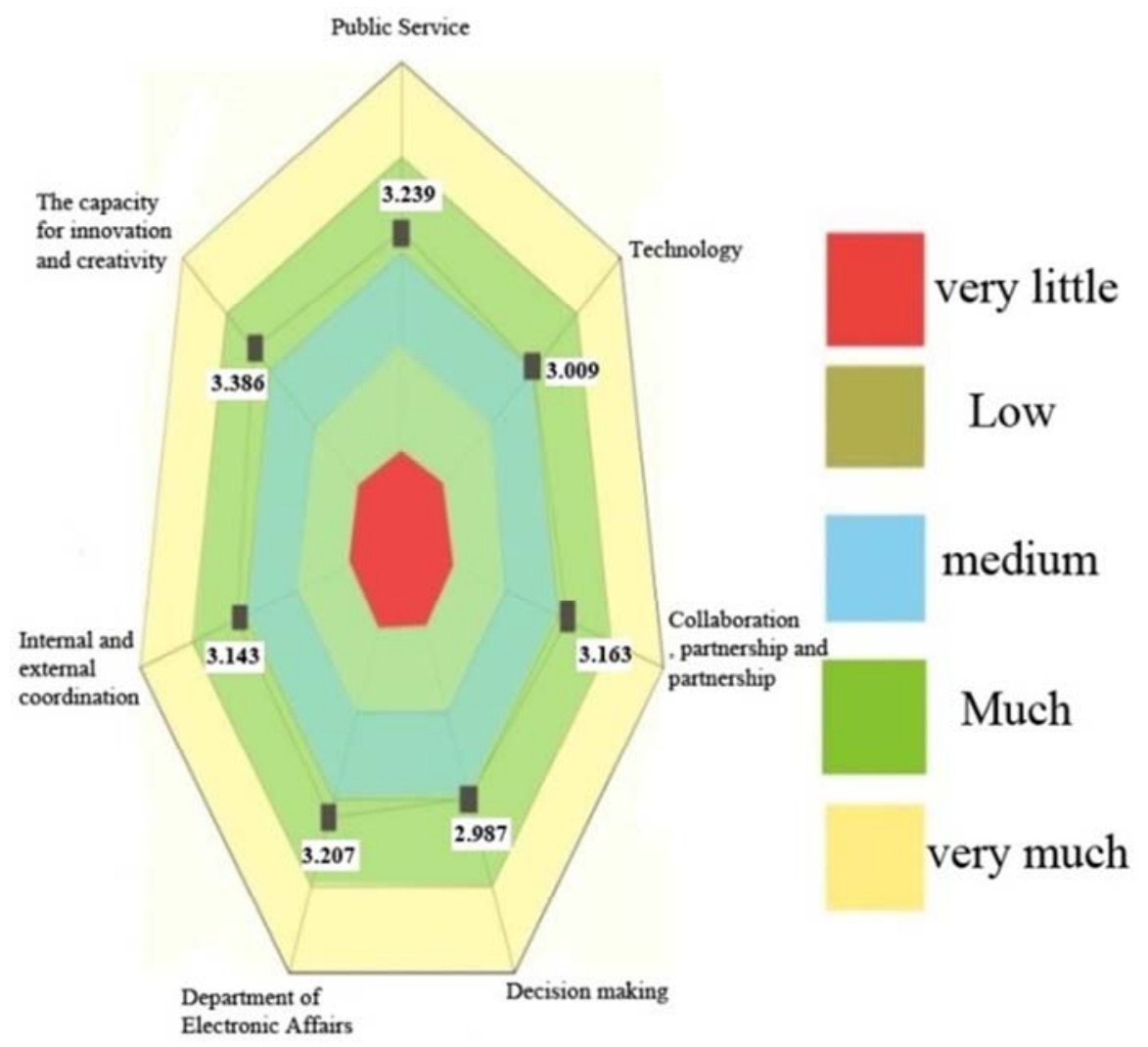

Figure 8. Status of Smart Governance Indicators in East Tehran (Western Tehranpars neighbourhood).

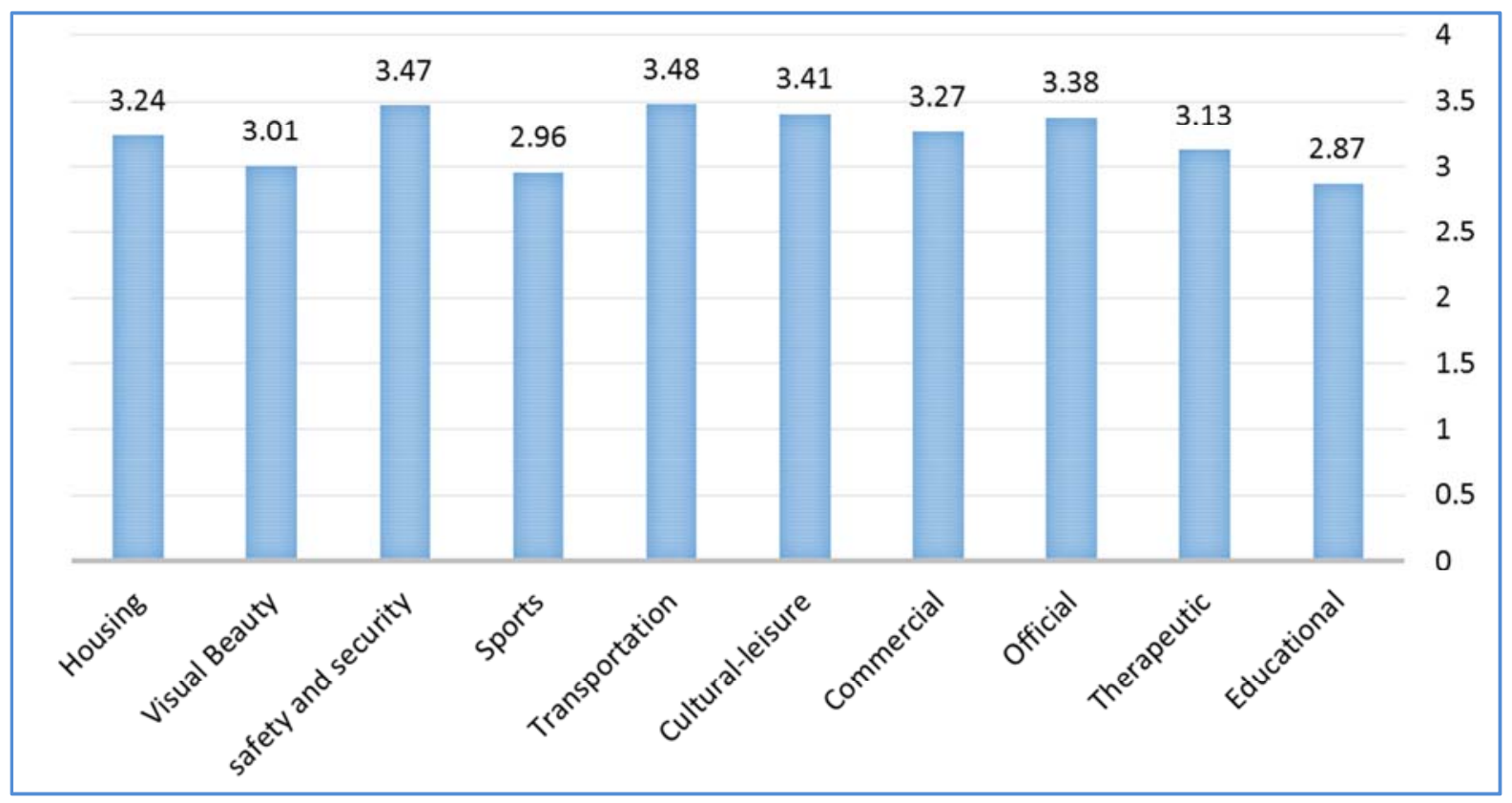

Figure 9. Status of public service sub-indicators in East Tehran ((Western Tehranpars neighbourhood).

\section{E) South of Tehran (Yaftabad neighbourhood)}

Examination of the results of the survey of smart governance indicators in the south of Tehran (Yaftabad neighbourhood) shows that except for internal and external coordination and decision-making actors that are lower than average, the other dimensions are average. According to the 2011 census, Internet penetration rate among the population of six years old and older in the eastern regions of Tehran is less than 36 per cent (region seventeen, 30.39\%).

Also, computer penetration rate in these areas (region 
seventeen, $58.45 \%$ ) is less than $60 \%$ and the population with higher education (higher than state diploma degree) is less

than $35 \%$ (area $17,30.09 \%$ ).

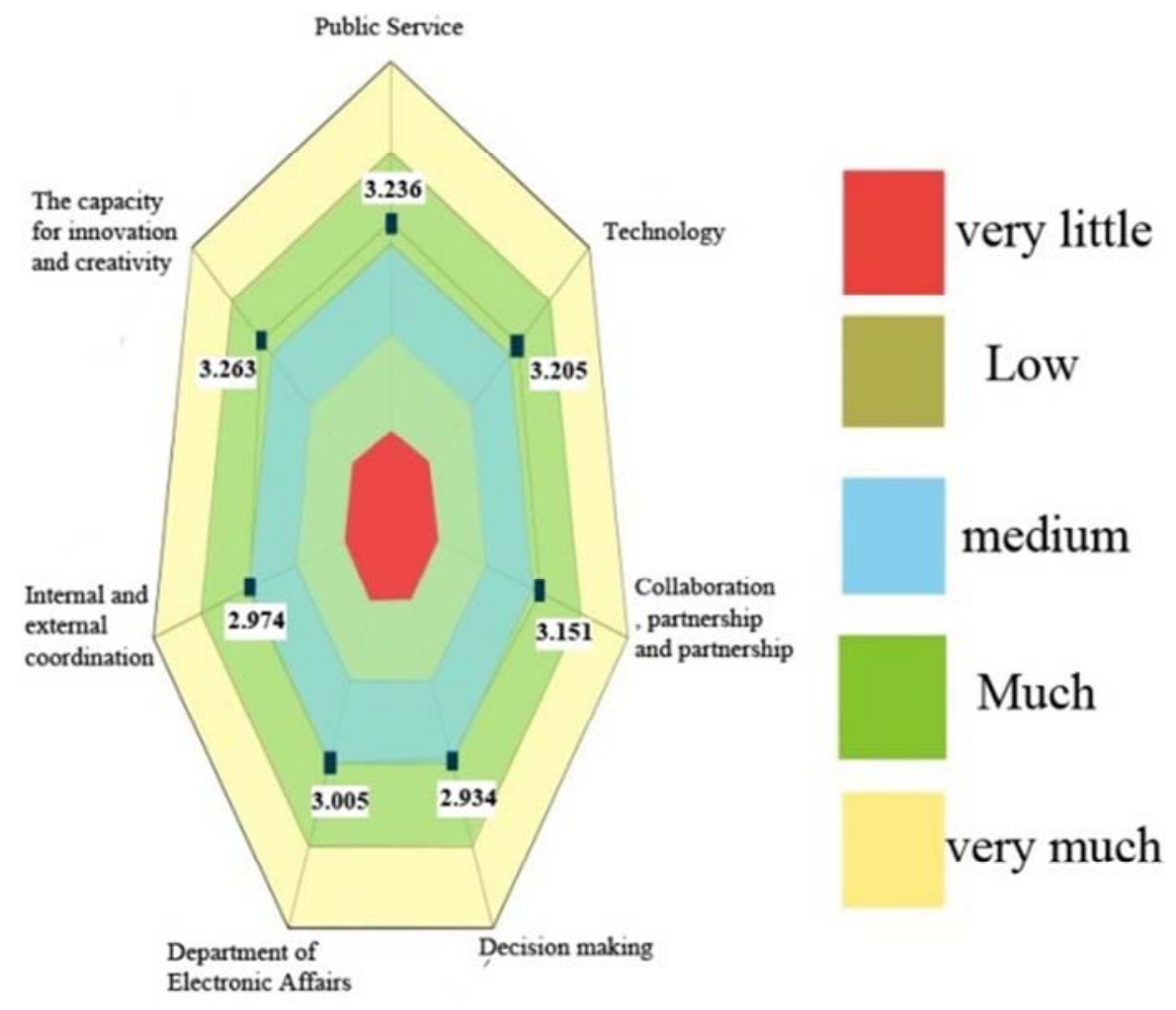

Figure 10. Status of Smart Governance Indicators in South Tehran (Yaftabad neighbourhood).

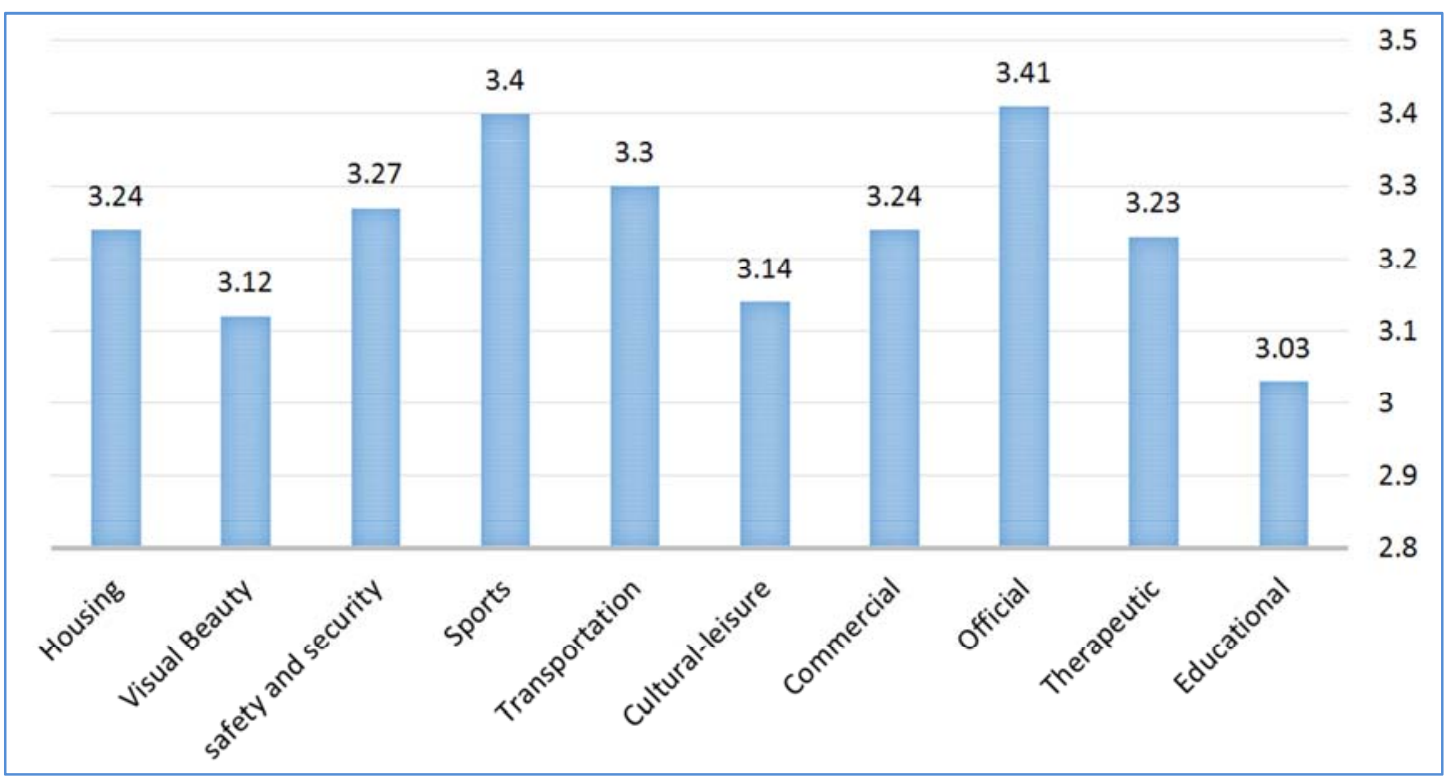

Figure 11. Status of public service sub-indices in the south of Tehran (Yaftabad neighbourhood).

\section{F) Total area under study (Tehran)}

The results of the survey of smart governance indicators in the whole study show that two basic dimensions of governance: participation, partnership and decision making as smart governance frameworks in Tehran are below average indicating role and Citizens have a weak position in the decision-making system. This reflects the management of the city based on the traditional model of bureaucracy. In spite of facilitating one-way communication between citizens, deep and meaningful and multilateral, through modern technologies in the world, in Tehran formal participation, unilateral and top-down, authoritarian relations have continued. The official statistics review also confirms this; According to the United Nations Economic and Social Department statistics in 2016, Iran is ranked 110th in terms of electronic participation. It also ranked 89th out of 175 
countries in 2016, according to the International Telecommunications Union (ICT) survey on ICT (Access, Use and Skills). The value of Internet access index in Iran in 2016 was 6.26 (ranked 79 in the world), internet use index was 2.74 (ranked 110 in the world) and the skill index was 6.96 (with Ranked 65 in the world). In addition, according to the United Nations Economic and Social Department statistics (based on three key dimensions of access to online services, telecommunications infrastructure and human capital), Iran ranks 193 member countries with an average of 0. 4507 in Asia (among 47 Country) has ranked 30th. It is also ranked 105th among all UN member states in this regard. Also, Iran's online services index is 0.3701 which is lower than the average Asian countries (0.4652). In the telecommunications infrastructure index, it is lower by 0.2940 than the average in Asia (0.3584). But the situation is different in the human capital index, so that the average Asian 0/6882 (6615/0) is slightly higher. Comparing Tehran's situation with that of other cities around the world shows that there is a significant gap between Tehran and these cities in terms of access to technology infrastructure. In terms of speed, internet access and internet bandwidth in different countries in 2008, New York City is at the forefront of metropolises with $100 \mathrm{Mbps}$. Among the developing countries, Ankara has the highest rank and Tehran has the lowest rate of $0.9 \mathrm{MB} / \mathrm{s}$.

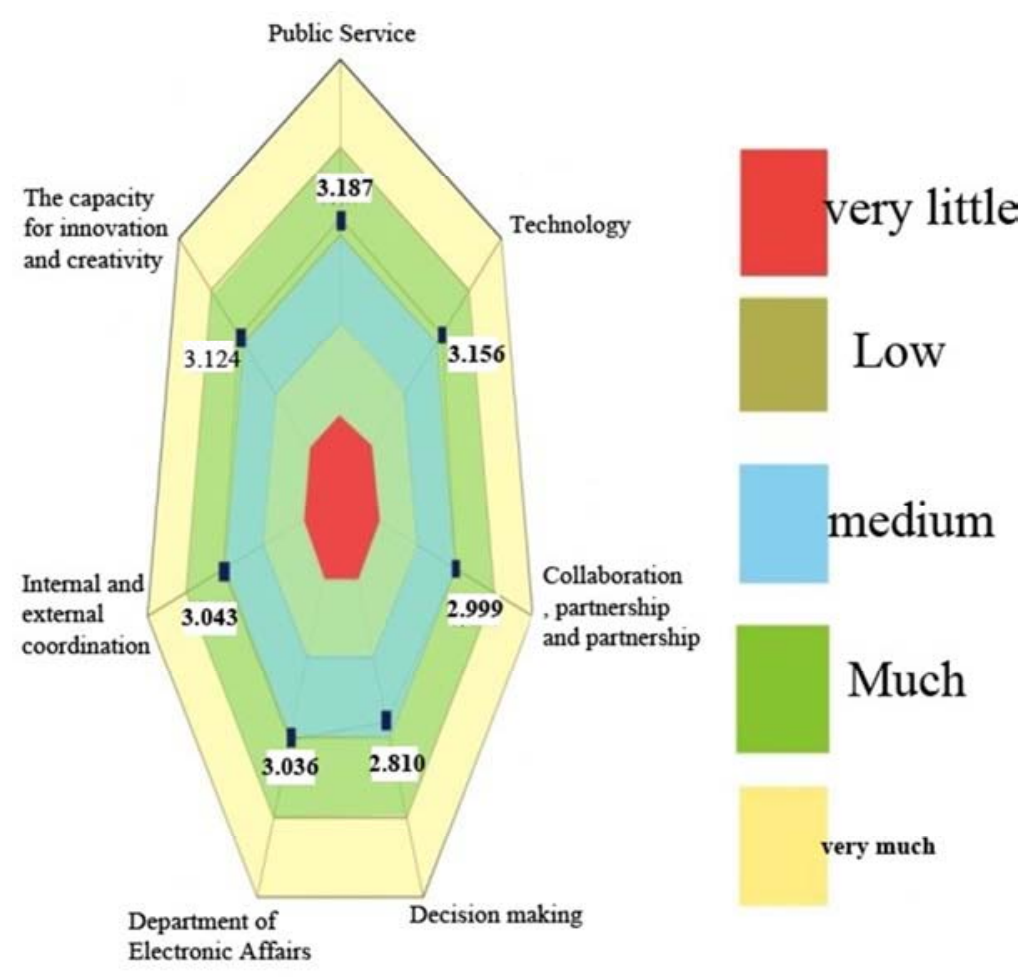

Figure 12. Status of Smart Governance Indicators in all surveyed neighbourhoods.

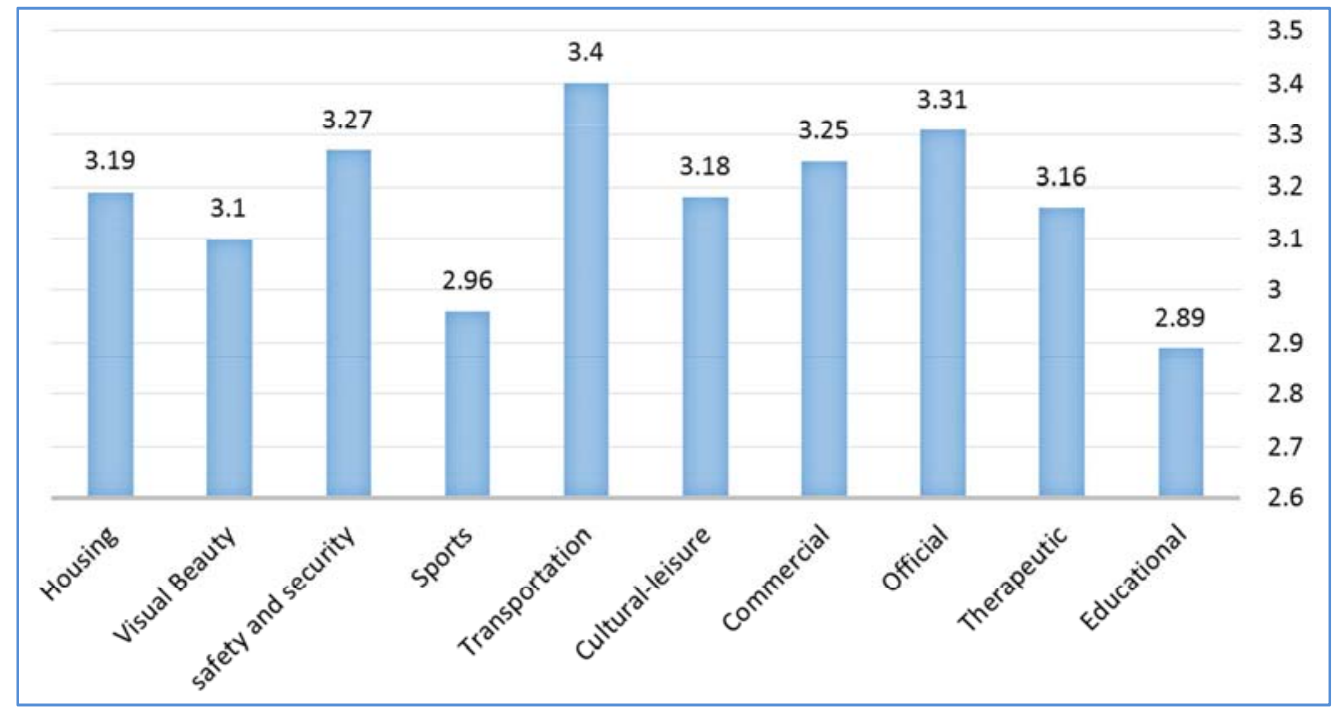

Figure 13. The status of public service sub-indicators across all neighbourhoods surveyed. 


\subsection{Ranking Smart Governance Criteria}

The Friedman test was used to rank the importance of smart city-based governance indices in each neighbourhood. The results of the Friedman test for ranking the importance of research indices differ based on the mean ratings in each neighbourhood and across the neighbourhoods studied. In the meantime, decision-making in all neighbourhoods is ranked last (7th). Compare the importance of smart governance indicators show that the residents of the neighbourhoods north and west of Tehran, the technology index, the index of public services, in the East and South of Tehran, capacity for innovation and creativity have won first place. A comparison of the importance of smart governance indices shows that in terms of technology index residents in north and west of Tehran, public services index in the centre, innovation capacity and creativity index in east and south of Tehran are ranked first.

Table 4. Prioritizing the importance of each of the indicators of smart governance in the study areas.

\begin{tabular}{|c|c|c|c|c|c|c|c|c|c|c|c|c|}
\hline \multirow{3}{*}{ Criteria } & \multicolumn{12}{|c|}{ Priorities based on Friedman test } \\
\hline & \multicolumn{2}{|c|}{ North (Velenjak) } & \multicolumn{2}{|c|}{ Center (Alexandri) } & \multicolumn{2}{|c|}{$\begin{array}{l}\text { West (South } \\
\text { Janet Abad) }\end{array}$} & \multicolumn{2}{|c|}{$\begin{array}{l}\text { East (West Pars } \\
\text { Tehran) }\end{array}$} & \multicolumn{2}{|c|}{ South (Yaftabad) } & \multicolumn{2}{|c|}{$\begin{array}{l}\text { All neighborhoods } \\
\text { surveyed }\end{array}$} \\
\hline & $\begin{array}{l}\text { Average } \\
\text { rating }\end{array}$ & Priority & $\begin{array}{l}\text { Average } \\
\text { rating }\end{array}$ & Priority & $\begin{array}{l}\text { Average } \\
\text { rating }\end{array}$ & Priority & $\begin{array}{l}\text { Average } \\
\text { rating }\end{array}$ & Priority & $\begin{array}{l}\text { Average } \\
\text { rating }\end{array}$ & Priority & $\begin{array}{l}\text { Average } \\
\text { rating }\end{array}$ & Priority \\
\hline Public Service & $4 / 61$ & 2 & $4 / 56$ & 1 & $4 / 83$ & 2 & $4 / 55$ & 2 & $4 / 37$ & 2 & $4 / 50$ & 1 \\
\hline Technology & $4 / 79$ & 1 & $3 / 74$ & 6 & $5 / 10$ & 1 & $3 / 15$ & 6 & $4 / 16$ & 3 & $4 / 30$ & 3 \\
\hline $\begin{array}{l}\text { Collaboration, partnership } \\
\text { and partnership }\end{array}$ & $3 / 77$ & 6 & $3 / 97$ & 5 & $3 / 25$ & 6 & $4 / 10$ & 4 & $4 / 07$ & 4 & $3 / 72$ & 6 \\
\hline Decision making & $3 / 01$ & 7 & $2 / 97$ & 7 & $2 / 64$ & 7 & $3 / 05$ & 7 & $3 / 27$ & 7 & $3 / 02$ & 7 \\
\hline $\begin{array}{l}\text { Department of Electronic } \\
\text { Affairs }\end{array}$ & $3 / 82$ & 5 & $3 / 99$ & 3 & $4 / 19$ & 3 & $4 / 24$ & 3 & $3 / 58$ & 5 & $4 / 04$ & 4 \\
\hline $\begin{array}{l}\text { Internal and external } \\
\text { coordination }\end{array}$ & $3 / 94$ & 4 & $4 / 44$ & 2 & $3 / 75$ & 5 & $3 / 97$ & 5 & $3 / 44$ & 6 & $3 / 95$ & 5 \\
\hline $\begin{array}{l}\text { The capacity for } \\
\text { innovation and creativity }\end{array}$ & $4 / 06$ & 3 & $4 / 33$ & 4 & $4 / 23$ & 4 & $4 / 94$ & 1 & $5 / 11$ & 1 & $4 / 46$ & 2 \\
\hline
\end{tabular}

\subsection{Comparison of the Priority of Each of the Indicators of Smart Governance Among the Neighbourhoods}

A comparison of the indicators between the surveyed neighbourhoods shows that public services were almost equally important. In the north of Tehran (Valenjak neighbourhood) the rest of the indicators are 1 to 3 , in the centre (Eskandari neighbourhood) 3 and 4, in the west (Janet
Abad neighbourhood) 2 to 5 , in the east (West Pars Tehran neighbourhood) 1 to 3 and in South (Neighborhood Finder), with the exception of the Innovation and Creativity Capacity Index (ranked \# 1), the rest ranked 3 to 5. This shows that citizens' preferences vary according to the individual and social values of individuals in different neighbourhoods on smart governance indicators.

Table 5. Comparison of the importance of smart governance indicators among the surveyed neighborhoods.

\begin{tabular}{|c|c|c|c|c|c|c|c|c|c|c|}
\hline \multirow{3}{*}{ Criteria } & \multicolumn{10}{|c|}{ Ranking of neighbourhoods based on Kruskal-Wallis test } \\
\hline & \multicolumn{2}{|c|}{ North (Velenjak) } & \multicolumn{2}{|c|}{$\begin{array}{l}\text { Center } \\
\text { (Alexandri) }\end{array}$} & \multicolumn{2}{|c|}{$\begin{array}{l}\text { West (South Janet } \\
\text { Abad) }\end{array}$} & \multicolumn{2}{|c|}{$\begin{array}{l}\text { East (West Pars } \\
\text { Tehran) }\end{array}$} & \multicolumn{2}{|c|}{ South (Yaftabad) } \\
\hline & $\begin{array}{l}\text { Average } \\
\text { rating } \\
\end{array}$ & Rating & $\begin{array}{l}\text { Average } \\
\text { rating }\end{array}$ & Rating & $\begin{array}{l}\text { Average } \\
\text { rating }\end{array}$ & Rating & $\begin{array}{l}\text { Average } \\
\text { rating }\end{array}$ & Rating & $\begin{array}{l}\text { Average } \\
\text { rating } \\
\end{array}$ & Rating \\
\hline Public Service & $219 / 89$ & - & $176 / 70$ & - & $183 / 67$ & - & $182 / 79$ & - & $209 / 46$ & - \\
\hline Technology & $221 / 52$ & 1 & $193 / 59$ & 4 & $203 / 27$ & 2 & $198 / 03$ & 3 & $152 / 28$ & 5 \\
\hline Collaboration, partnership and partnership & $216 / 06$ & 1 & $190 / 22$ & 4 & $154 / 31$ & 5 & $208 / 32$ & 2 & $203 / 84$ & 3 \\
\hline Department of Electronic Affairs & $202 / 04$ & - & $200 / 51$ & - & $175 / 90$ & - & $200 / 81$ & - & $193 / 11$ & - \\
\hline Internal and external coordination & $205 / 01$ & 2 & $191 / 03$ & 3 & $177 / 68$ & 4 & $225 / 91$ & 1 & $168 / 52$ & 5 \\
\hline The capacity for innovation and creativity & $193 / 18$ & 3 & $177 / 89$ & 4 & $166 / 37$ & 5 & $206 / 59$ & 2 & $225 / 72$ & 1 \\
\hline
\end{tabular}

\section{Conclusion}

The reality is that in smart cities the balance of power is changing more rapidly. Clearly, citizens need their governments and governments need the intelligence and cooperation of their citizens to function well. These demands change the way cities are run. The idea of smart city governance, which fits well into the public management perspective, emphasizes social problem-solving and is not simply a call for the development of good policies, but rather a management request for the organization of cooperation between the government and other stakeholders in different dimensions. The traditional bureaucratic and classical model of governance is currently unable to meet the growing needs and demands of today, and cities need a new form of governance called smart governance. In the meantime, the results of this research on smart governance indicators in Tehran show that two basic dimensions of governance (participation, partnership and decision making) are below average. This reflects the 
weak role and status of citizens in decision-making and decision-making. The situation of other smart governance indicators in Tehran is also moderate. While most of the indices studied are moderate, they are better in the north and east of Tehran than in the west, centre and south. This situation shows the gap in different parts of Tehran in terms of smart governance indicators. This is more evident in the 22 districts of Tehran (based on objective statistics). Therefore, according to the results of the research, to enter the smart city in Tehran requires the necessary platforms, especially the development of telecommunication infrastructure in the first priority, the production of content and applications tailored to the needs of the citizens (subject to updating) in the second priority, and paying attention to human capabilities in the third priority. This can lead to equal use of opportunities (in order to reduce the digital divide) and reduce other issues. To reduce problems in Tehran and playing an active and effective role in the world (interaction with stakeholders within and outside the city) moving towards smart is inevitable. The continuation of the current process (traditional and top-down management and governance institutions and practices in opposition to the complex and rapidly changing world of the information society) does not lead to the realization of a smart city in Tehran.

The development of an efficient and effective urban government is an essential prerequisite for the development of the smart city of Tehran. This requires not only the improvement of the capacity of the public sector, but also the transformation of the role, scope, and activities of urban governments in the economy and society. Failure to pay attention to this, in the long run, can have irreparable risks. On the other hand, as the world moves towards smart cities, cities and citizens are bound to join the trend in order to interact and continue their lives in different dimensions and play an active role. This can have a negative role in the development of the city and for the loss of global and transnational opportunities and its unsuccessful reproduction without providing the requisites and background for the deployment of the smart city. On the other hand, if not implemented properly and efficiently, in addition to technology dependency, it may marginalize sections of the population that are unable to adapt to this new way of urban life and their ability to meet their needs within the city difficulty, and it actually creates a kind of social polarization and a digital divide. Smart governance as the cornerstone of the smart city and as its starting point has five key dimensions; "decision-making, partnership, collaboration and taking part, internal and external coordination, innovation capacity, technology, and egovernment." The integration and interrelationships of these five factors through the sharing of knowledge and information can generate public value, and this underpins social learning and then social innovation in the city. In addition, this collective intelligence resulting from the combination of the above factors will transform the city and thus provide better services to the citizens that will enhance the quality of life in the city. For smart governance in Tehran legislation, formulation of integrated policies and a long-term vision is essential (this is a long process and can not be achieved overnight).

\section{References}

[1] Alawadhi, A. Aldama-Nalda, H. Chourabi, J. R. Gil-Garcia, S. Leung, S. Mellouli, T. Nam, T. A. Pardo, H. J. Scholl, S. (2012). Building Understanding of Smart City Initiatives," Lecture Notes in Computer Science 7443. 40-53.

[2] Albino, V. Beradi, U. Dangelico, R. M. (2015). Smart Cities: Definitions, Dimensions, Performance, and Initiatives. Journal of Urban Technology. 22 (1): 3-21.

[3] Anastasia, S (2012). The concept of smart cities: Towards community development? Networks and Communication Studies, NETCOM, vol 26: 375-388.

[4] Barrionuevo, J. M., Berrone, P., \& Ricart, J. E. (2012). Smart cities, sustainable progress. IESE Insight, 14 (14), 50-57.

[5] Bătăgan, L. (2011). Smart Cities and Sustainability Models. InformaticaEconomică, 15 (3), 80-87.

[6] Batty, M., Axhausen, K. W., Giannotti, F., Pozdnoukhov, A., Bazzani, A., Wachowicz, M.,... \& Portugali, Y. (2012). Smart cities of the future. The European Physical Journal Special Topics, 214 (1), 481-518.

[7] Bolívar, M. P. R., \& Meijer, A. J. (2016). Smart Governance: Using a Literature Review and Empirical Analysis to Build a Research Model. Social Science Computer Review, 34 (6), 673-692.

[8] Capra, C. F. (2014). The Smart City and its Citizens: Governance and Citizen Participation in Amsterdam Smart City. Master thesis. Lund university.

[9] Caraglhiu, A. (2009). Smart Cities in Europe. 3rd Central European Conference in Regional Science - CERS. A13, L90, O18, R12.

[10] Caragliu, A., Del Bo, C. and Nijkamp, P. (2009). Smart Cities in Europe. Proceedings to the $3^{\text {rd }}$.

[11] Castelnovo, W., Misuraca, G., Savoldelli, A. (2015). Smart Cities Governance: The Need for a Holistic Approach to Assessing Urban Participatory Policy Making. Social Science Computer Review: 1-16.

[12] Chourabi, H. Taewoo, N. Shawn, W. J. Ramon, G. G. Sehl Mellouli, K. N. Theresa, A. P. \& Hans J. S. (2012). Understanding smart Cities: An integrative framework. 2012 45th Hawaii International Conference on System Sciences: 2289-2297.

[13] Coe, A., Paquet, G., \& Roy, J. (2001). E-governance and smart communities: a social learning challenge. Social science computer review, 19 (1), 80-93.

[14] Cohen, B. (2012). The top 10 smart cities on the planet, CoExist, 17 January. Available online at: http://www.fastcoexist.com/1679127/the-top- 10-smart-citieson-the-planet ]Accessed 17 April 2013].

[15] Colldahi, C. Frey, S. \&Kelemen, J. E. (2013). Smart Cities: Strategic Sustainable Development for an Urban World. (Master thesis). Karlskronauniversity. Sweden. 
[16] Copenhagen Cleantech Cluster. (2012). Danish Smart Cities: Sustainable Living in an Urban World. Copenhagen Cleantech Cluster: 2-41.

[17] Damer, P. R and Benevolo, C (2015). Governing Smart Cities: An Empirical Analysis. Social Science Computer Review 115 .

[18] David, N., Justice, J., \& McNutt, J (2015). Smart Cities Are Transparent Cities: The Role of Fiscal Transparency in Smart City Governance. Public Administration and Information Technology, Library of Congress Control Number: 2015944231: 69-86.

[19] Dirks, S. Constantin, G., \& Mary Keeling. (2010). Smarter cities for smarter growth. IBM GlobalBusinessservicesExecutiveReport. http://public.dhe.ibm.com/common/ssi/ecm/en/gbe03348usen/ GBE03348USEN.PDF (accessed 17 April 2013).

[20] Ferraro, S. (2013). Smart Cities, Analysis of a Strategic Plan. (Master thesis).

[21] Fung, A. (2006). Varieties of participation in complex governance. Public Administration Review, 66 (s1), 66-75.

[22] Giffinger, R. and Gudrun, H. (2010). Smart cities ranking: An effective instrument for the positioning of cities? ACE: Architecture, City and Environment 4, 12, 7-25.

[23] Giffinger, R., Fertner, C., Kramar, H., Meijers, E., \& PichlerMilanovic', N. (2007). Smart cities: Ranking of European medium-sized cities. Vienna, Austria. Retrieved from http://www.smartcities.eu/download/smart_cities_final_report.pdf.

[24] Giffinger, R., Kramar, H., \& Haindl, G. (2008). The Role of Rankings in Growing City Competition. In Proceedings of the $11^{\text {th }}$ European Urban Research Association (EURA) Conference. Milan, Italy, October 9-11, Available from http://public.Tuwien.ac.At/files/ pubdat_167218.Pdf.

[25] Gil-Garcia R (2012) Enacting Electronic Government Success An Integrative Study of Government-wide Websites, Organizational Capabilities, and Institutions. New York: Springer.

[26] Gil-Garcia, J. Ramon, Theresa A. Pardo, and Taewoo Nam. "What makes a city smart? Identifying core components and proposing an integrative and comprehensive conceptualization." Information Polity 20.1 (2015): 61-87

[27] Gonçalves, S. (2014). The effects of participatory budgeting on municipal expenditures and infant mortality in Brazil. World Development, 53 (0), 94-110.

[28] Hepburn, p (2015). Smart Cities: Just how clever does local government need to be? Lessons from a case study on cocreating digital applications for elderly people. the RC21 International Conference on "The Ideal City: between myth and reality. Representations, policies, contradictions and challenges for tomorrow's urban life" Urbino (Italy) 27-29 August 2015.

[29] Kitthananan, A. (2006). Conceptualizing governance. A review. Journal of Societal.

[30] Kourtit K, Nijkamp P and Arribas D (2012) Smart cities in perspective - a comparative European study by means of selforganizing maps. Innovation: The European Journal of Social Science Research 25 (2): 229-246.
[31] Lindskog, H. (2004). Smart communities initiatives. In Proceedings of the 3rd ISOne World Conference (Las Vegas,

[32] McKinsey Global Institute. 2011. Urban world: Mapping the economic power of cities.

[33] Meijer (2013) Governing the Smart City: Scaling-Up the Search for Socio-Techno Synergy. Permanent Study group on E-Government, Utrecht University.

[34] Meijer, A. J., \& Rodríguez Bolívar, M. P. (2013). Governing the Smart City: Scaling-Up the Search for Socio-Techno Synergy. Paper presented at EGPA Conference 2013, Edinburgh, Scotland.

[35] Mosannenzadeh, F. Vettoratob. D. (2014). Defining smart city: Aconcepttual frame work based on key word analaysis. Journal of Land Use, Mobility and Environment. ISSN 19709889, e- ISSN 1970-9870.

[36] Nam, T. \&Pardo, T. A. (2011). Conceptualizing Smart City with Dimensions of Technology, People, and Institutions, in Proceedings of the 12th Annual Digital Government Research Conference, College Park, Maryland, June 12-15.

[37] Nam, T. (2012). Modeling municipal service integration: A comparative case study of New York and Philadelphia 311 systems. State University of New York at Albany.

[38] Nam, T., Pardo, T. A. (2011). Smart City as Urban Innovation: Focusing on Management, Policy, and Context. ICEGOV Tallin, Estonia.

[39] Nam, Taewoo, and Theresa A. Pardo. 2011. Conceptualizing Smart City with Dimensions of Need for a Holistic Approach to Assessing Urban Participatory Policy Making. Social Science Computer Review 1-16.

[40] Odendaal, N. (2003). Information and communication technology and local governance: Understanding the difference between cities in developed and emerging economies. Computers, Environment and Urban Systems, 27 (6), 585-607.

[41] Pinnegar, S., Marceau, J., and Randolph, B. (2008). Innovation for a carbon-constrained city: Challenges for the built environment industry. Innovation: Management, Policy \& Practice 10, 2-3, 303-315.

[42] Schaffers, H. Komninos, N. Pallot, M. Trousse, B. Nilsson, M. Oliveira, A (2011). Smart Cities and the Future Internet: Towards Cooperation Frameworks for Open Innovation. Future Internet Assembly, LNCS 6656, pp. 431-446.

[43] Schuurman D, Baccarne B, De Marez L and Mechant P (2012) Smart ideas for smart cities: Investigating crowdsourcing for generating and selecting ideas for ICT innovation in a city context. Journal of Theoretical and Applied Electronic Commerce Research 7 (3): 49-62.

[44] Shapiro, J. M. (2006). Smart cities: quality of life, productivity, and the growth effects of human capital. The review of economics and statistics, 88 (2), 324-335.

[45] Stratigea, A. (2012). The concept of 'smart cities'. Towards community development? Networks and Communication Studies, Netcom, 26-3/4.

[46] Tapscott D and Agnew D (1999) Governance in the digital economy: The importance of human development. Finance \& Development 36 (4): 34-37. 
[47] Theodore, N., \& Peck, J. (2012). Framing neoliberal urbanism: Translating 'commonsense'urban policy across the OECD zone. European Urban and Regional Studies, 19 (1), 20-41.

[48] Walravens, N. (2012). Mobile Business and the Smart City: Developing a Business Model.

[49] Walravens, N. (2012). Mobile business and the smart city: Developing a business model framework to include public design parameters for mobile city services. Journal of theoretical and applied electronic commerce research, 7 (3), 121-135.
[50] Willke, H. (2007). Smart governance: Governing the global knowledge society. New York, NY: Campus Verlag.

[51] Winters, J. V. (2011). Why are Smart Cities Growing? Who Moves and Who Stays. Journal of Regional Science. 51 (2). 253-270. 